\title{
Friedman and Phelps on the Phillips curve viewed from a half century's perspective
}

\author{
Robert J. Gordon* \\ Northwestern University, Evanston, IL and National Bureau of Economic Research (NBER), Cambridge, \\ MA, USA
}

In the late 1960s the stable negatively sloped Phillips curve was overturned by the Friedman-Phelps natural rate model. Their Phillips curve was vertical in the long run at the natural unemployment rate, and their short-run curve shifted up whenever unemployment was pushed below the natural rate. This paper criticizes the underlying assumption of the Friedman-Phelps approach that the labor market continuously clears and that changes in unemployment down or up occur only in response to 'fooling' of workers, firms, or both. A preferable and resolutely Keynesian approach explains quantity rationing by inertia in price and wage setting. The positive correlation of inflation and unemployment in the 1970 s and again in the 1990s is explained by joining the negatively sloped Phillips curve with a positively sloped dynamic demand curve. For any given growth of nominal $G D P$, higher inflation implies slower real GDP growth and higher unemployment. This 'triangle' model based on demand, supply, and inertia worked well to explain why inflation and unemployment were both positively and negatively correlated between the 1960s and 1990s, but in the past decade the slope of the short-run Phillips curve has flattened as inflation exhibited a muted response to high unemployment in 2009-2013 and low unemployment in 2016-2018.

Keywords: unemployment, inflation, Keynesian model, price inertia, supply shocks, natural rate

JEL codes: $B 22, C 22, E 24, E 31, E 64$

\section{INTRODUCTION}

The dominant approach to inflation dynamics in the late 1960s was to posit a trade-off between inflation and unemployment along a negatively sloped Phillips curve (PC) that could be exploited by policymakers. A lower unemployment rate could be achieved by expansionary demand policy at the sacrifice of a finite and stable extra amount of inflation. Policy discussions were framed in terms of points of tangency between the convex $\mathrm{PC}$ and concave inflation-unemployment indifference curves. Democrats were said to have steeper indifference curves than Republicans and thus to choose an equilibrium with lower unemployment and higher inflation.

This framework was challenged in two articles by Edmund Phelps $(1967 ; 1968)$ and in Milton Friedman's (1968) presidential address to the American Economics Association.

* This research has been supported by the Smith-Richardson Foundation. I am grateful to Hassan Sayed for help with the references. 
Phelps and Friedman argued that there was a separate short-run PC for each expected rate of inflation. Starting at an initial equilibrium unemployment rate $\left(U^{*}\right)$ where both the actual and expected inflation rates were equal, any attempt to reduce the unemployment rate below $U^{*}$ would boost actual above-expected inflation, and expected inflation would then rise one-for-one in response, shifting the short-run PC upwards. This process of upward shifting would continue as long as the unemployment rate remained below $U^{*}$. Any attempt by policymakers to hold $U$ below $U^{*}$ would fuel a continuously accelerating inflation. In the long run the PC was vertical at $U^{*}$.

The natural rate revolution of Friedman and Phelps overturned the policy-exploitable trade-off in favor of long-run monetary neutrality. But there was still a short-run tradeoff that could persist for several years, due to the choice by both authors to model inflation expectations as adaptive, that is, depending on past realized values of inflation. Only a few years later Robert Lucas $(1972 ; 1973)$ together with Thomas Sargent and Neil Wallace (1975) claimed to have overturned the short-run trade-off by arguing that expectations were 'rational' as economic agents and could anticipate in advance any demand-expansion policy that was based on a predictable monetary rule. Since a reduction of unemployment required an error in forecasting inflation, any predictable change of inflation could not alter the unemployment rate. In short, according to this 'policy-ineffectiveness proposition' (PIP) only an unanticipated 'surprise' monetary-driven demand expansion could affect the actual unemployment rate.

Often events influence the adoption of ideas. The acceleration of actual US inflation in the late 1960s beyond contemporary forecasts before long provided convincing evidence of the basic expectations-shifting approach of Friedman and Phelps that underpinned their long-run neutrality result and defeated those conducting a rearguard defense of a permanent negative unemployment-inflation trade-off. Then in 1974-1975 the simultaneous arrival of a sharp spike of additional inflation together with a deep recession showed that inflation and unemployment could be positively correlated, and this further evidence against the negative trade-off was used by Lucas and Sargent (1978) to announce the 'wreckage' of Keynesian macroeconomics.

This paper provides a critique of the underlying assumption of the Friedman-Phelps approach that the labor market continuously clears and that changes in unemployment down or up occur only in response to 'fooling' of workers, firms, or both. The Friedman model can generate a rise of unemployment only if workers voluntarily choose to work less in response to a decline in the expected real wage, a mechanism contradicted by involuntary lay-offs that occur in the real world at the prevailing level of wages and prices. The Friedman-Phelps approach is contrasted with my 'triangle model' (Gordon 1982b) in which long lags of inflation relative to the history of inflation are interpreted as due to multiple-period wage and price contracts as well as delays in price-setting as intermediate goods move through the input-output table. This approach is resolutely Keynesian, as the inertia in the inflation process prevents markets from clearing, so that a downward shift in nominal demand growth is translated automatically into a downward shift in real demand growth with accompanying quantity rationing in labor and product markets.

In addition to inertia, the other two sides of the triangle model represent demand and supply. The demand side operates through the unemployment gap relative to the natural rate, so that the model incorporates the natural rate hypothesis (NRH). The supply side incorporates the positive impact on inflation of adverse supply shocks such as jumps in the price of oil, and the model can thus explain why inflation and unemployment are sometimes negatively and sometimes positively correlated 
while preserving Keynesian economics from the 'wreckage' proclaimed by Lucas and Sargent.

The final sections of the paper review major developments in the behavior of inflation relative to unemployment since the 1970s. While coefficients in the triangle model were relatively stable in the 1980s and 1990s, relationships appear to have shifted since then. The supply-side responses have become muted as the effects of oil prices on overall inflation have diminished, the slope of the short-run inflation-unemployment relationship has flattened, and the response of current to past inflation has diminished as expectations appear to have become more anchored at the 2 percent inflation target of the Federal Reserve. These changes are profound enough that Olivier Blanchard (2016) has recently suggested that we may have gone full-circle back to the 1960sstyle trade-off that Friedman and Phelps revolted against.

\section{THE PC TRADE-OFF AS INTERPRETED IN THE EARLY TO MID 1960s}

The PC began as the result of an empirical investigation of UK wage behavior by Phillips (1958). The relationship had originally been investigated by Irving Fisher 30 years previously in a long-neglected paper (1926) that was rediscovered and reprinted in 1972. The PC was christened and brought to America by Paul Samuelson and Robert Solow (1960). The phrase caught on immediately, and soon the relationship became a central component of the large-scale econometric models that were being developed in the 1960s as increasing computer power made them possible.

Samuelson and Solow examined a scatter-plot of the data for the US and noted that the Phillips relationship did not work either for the 1930s or for the two world wars. The zero-inflation unemployment rate had risen from 3 percent in the remaining prewar years to ' 5 to 6 percent' in the 1950s. Samuelson and Solow have rightly been criticized for posing a long-run inflation-unemployment tradeoff available for exploitation by policymakers. They conclude: 'We rather expect that the tug of war of politics will end us up in the next few years somewhere in between their selected points. We shall probably have some price rise and some excess unemployment' (Samuelson and Solow 1960, p. 103).

In defense of Samuelson and Solow, they did recognize that the PC relationship could shift over the longer run. Their examples involved a 'low-pressure' (that is, high-unemployment) economy in which expectations of low inflation could shift the PC down, or alternatively a shift to more structural unemployment that could shift the PC up. They regarded either outcome as possible and notably failed to reason through the long-run implications of a high-pressure economy with the possibility of a steady increase in inflation expectations and an associated steady upward shift in the PC.

As shown in Figure 1 (overleaf), the unemployment rate fell below 5.5 percent in 1964 and remained below 4 percent between 1966 and 1970. The sharp acceleration of inflation (shown here as the four-quarter change in the deflator for personal consumption expenditures) from less than 2 percent in 1963 to 5.5 percent in 1970 is consistent with current estimates that the natural rate of unemployment in the mid 1960s was in the range of 5.5 to 6.0 percent. Samuelson and Solow would have predicted that four straight years of unemployment below 4 percent would have been compatible with a steady 3 percent inflation, whereas we can see in Figure 1 that inflation continually accelerated from 1966 to 1970. 


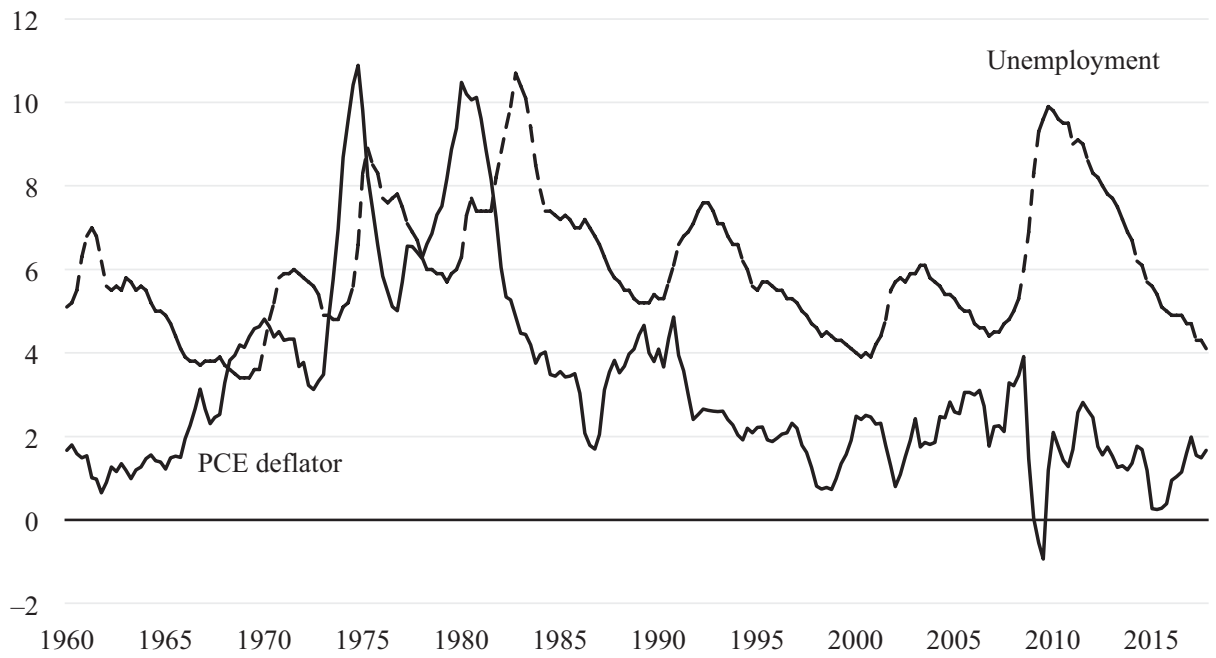

Figure 1 Unemployment rate vs four-quarter growth rate of headline personal consumption deflator, 1960Q1-2017Q4

\section{THE NATURAL RATE REVOLUTION}

The first formal rejection of the negatively sloped long-run PC trade-off was published by Phelps (1967). There was no explicit modeling of worker or firm behavior, but, rather, a simple model with three elements. First, the negatively sloped short-run PC determined the rate of price change, with no mention of wage change, and responded one-for-one to changes in the expected rate of inflation. Second, expected inflation responded gradually over time to movements in the actual inflation rate. Third, a social utility function depended negatively on the rate of unemployment and on the expected rate of inflation. The inflation rate was constant and equal to the expected inflation rate only at the long-run equilibrium rate of employment $U^{*}$. At any $U<U^{*}$ inflation exceeded expected inflation and so expectations were continually revised upwards, thus shifting actual inflation up one-for-one, until $u$ returned to $U^{*}$.

The optimal policy choice depended on society's rate of time preference and on the optimal rate of inflation $\pi^{*}$, that which was consistent with a nominal interest rate 'low enough to satiate the transaction demand for liquidity by eliminating private efforts to economize on cash balances' (Phelps 1967, p. 256). With a zero rate of time preference future considerations dominated, and policymakers should drive the inflation rate down to $\pi^{*}$ even if that required a temporary period of underemployment. If the rate of time preference was positive, then policymakers should temporarily drive down the unemployment rate to enjoy the benefits of high employment and utilization at the cost of a future inflation rate $\pi>\pi^{*}$. The degree of temporary overemployment, and hence the future rate of inflation, depended positively on the rate of time preference. Similarly, if the economy were to start out with $\pi>\pi^{*}$, then with a positive rate of time preference a deliberate raising of unemployment in a recession might be rejected if the near-term social cost of extra unemployment was judged to exceed the long-term benefits of reducing $\pi$ to $\pi^{*}$. 
In part because it contained a thicket of equations, and in part because it was published in a British journal, Phelps's 1967 article did not have nearly as much impact on the economics profession as Friedman's (1968) presidential address to the American Economics Association. ${ }^{1}$ Friedman made the same basic point as Phelps (1967), that policymakers had no ability to choose any arbitrary unemployment rate in the long run other than what Friedman called the 'natural rate of unemployment,' the same concept as Phelps's long-run equilibrium rate of unemployment $U^{*}$. This unemployment rate would be 'ground out' by the microeconomic structure of product and labor markets. As in Phelps, the natural rate was the only unemployment rate consistent with the accurate formation of expectations, which required a constant actual rate of inflation equal to the expected rate. Phelps's long-run equilibrium theory became Friedman's 'natural rate hypothesis' (NRH).

Friedman's argument was set in the framework of an explicit verbal model of the labor market. Since the nominal wage was evaluated in terms of the current actual product price by employers and in terms of the expected average consumer price level by workers, employment could increase only as long as the expected price level lagged behind the actual level (thus simultaneously allowing a lower actual real wage to induce increased hiring by firms, and a higher expected real wage to induce a higher labor supply by workers). In equilibrium the expected and actual price level were equal, and so in equilibrium only one level of employment and output was possible.

The timing of Phelps's two articles $(1967 ; 1968)$ and of Friedman's address was impeccable and even uncanny, as we have seen in Figure 1 that inflation was in the process of continually accelerating during 1966-1970 as the unemployment rate remained below 4 percent, clearly below the natural unemployment rate. ${ }^{2}$ The acceleration of inflation bewildered contemporary econometricians, who had previously estimated a 'full-employment' unemployment rate of 4 percent and whose forecasts of inflation had been exceeded by the actual outcome year after year. The inflation outcome also tainted Arthur Okun's (1962) concept of 'potential output,' which he had estimated as the value of real GDP consistent at any given time with a 4 percent unemployment rate.

The initial reaction by many economists to the NRH was that its policy implications could be ignored because it was inconsistent with US data. In regressions of the inflation rate on the expected inflation rate and the unemployment rate, at least up until 1971 the estimated coefficient $(\alpha)$ on expected inflation (proxied by lags on past inflation) was less than unity, in contrast to the Friedman-Phelps assumption that the PC shifted one-for-one with changes of expected inflation. Two sets of influences soon defused this line of criticism. First, the acceleration of inflation in the late 1960s caused the computer to grind out ever higher values of the $\alpha$ coefficient as the passage of time provided additional observations until finally tests with a sample period extending to 1971 could not reject the hypothesis that $\alpha=1$. Second, Sargent (1971) provided the compelling argument that a coefficient $\alpha<1$ did not imply that inflation responded less than one-for-one to expected inflation, because expectations of inflation themselves could be optimally formed by placing less than a weight of unity

1. Friedman's address was delivered in December 1967 and published in May 1968. Friedman's approach was set out informally two years earlier in Friedman (1966).

2. I have always thought that Friedman's development of the NRH at Chicago reflected the deep involvement during the 1960s of several Chicago economists as advisors to high-inflation countries in Latin America, where the lack of correlation between inflation and unemployment was obvious. 
on past inflation values, depending on the time-series properties of the inflation process.

Embarrassed by their failure to forecast the acceleration of inflation, Friedman's detractors attacked the verbal model that he used to motivate the NRH. In what others labeled the 'fooling' model, Friedman postulated that employers had expectations of the price level that were always accurate, but that workers based their decisions on an expected price level that did not respond until after a substantial lag to a higher actual price level. In a business expansion, firms raised the wage but raised the price level by even more, thus reducing the real wage as needed to provide the incentive to hire additional workers. But workers saw the higher nominal wage and interpreted it as a higher actual real wage, because they failed to adjust their expectations of the price level. This model of smart firms and dumb workers was attacked as inherently implausible, because workers had access to monthly announcements of the Consumer Price Index and indeed observed actual prices as they shopped almost every day. In Friedman's world, there could be no business cycle.

Phelps wrote a second paper (1968) that provided a formal model of behavior that differed from Friedman's but was subject to the same criticism. In contrast to Friedman's smart firms and dumb workers, in Phelps's world everyone was dumb, that is, equally fooled. Both firms and workers saw the price rise in their industry and produced more, not realizing that the general price level had risen in the rest of the economy. Normally there was frictional unemployment, as workers regularly quit one firm to go look for more highly paid work at other firms. But in a situation in which their own firm raised the wage, they stayed with that firm instead of quitting. Thus the unemployment rate decreased even though, without that knowledge, all other firms in the economy raised the wage by the same amount at the same time. The workers were fooled into a reduction in frictional unemployment, and the macroeconomic data registered a decline in the unemployment rate. Hence there was a short-term correlation between the rate of wage change and the unemployment rate, but this lasted only as long as expectations were incorrect.

Whether firms or workers or both were fooled, the criticisms directed against the Friedman fooling model applied to Phelps as well, as firms and workers shared knowledge of the latest announcements of the aggregate price level every month. If periods of high real GDP and low unemployment had always been accompanied by an increase in the aggregate price level, workers and firms would have learned from these past episodes and would have used their experience to form expectations accurately.

\section{RATIONAL EXPECTATIONS AND THE 'POLICY INEFFECTIVENESS PROPOSITION'}

Both the Friedman and Phelps models were based on the twin assumptions of continuous market clearing and imperfect information, and only incorrect information could push the economy away from its natural rate. There was no rationing in product or labor markets, and no involuntary lay-offs. Soon thereafter, in two influential articles, Lucas $(1972 ; 1973)$ extended their models by adding a third component: rational expectations. Workers and firms used their knowledge of past history to work out the implications of an observed fall or rise in wages on the overall wage level. Rational expectations implied that erroneous expectations errors were not repeated. 
Lucas collapsed the distinction between firms and workers and treated all economic agents as 'yeoman farmers' who faced both idiosyncratic shocks to their own relative price and macro shocks caused by fluctuations in monetary growth and other factors. The agents used rational expectations to deduce from past history how much of an observed change in the local price represented an idiosyncratic shock and how much represented a macro shock. When local price shocks had a high correlation with macro shocks, agents did not adjust production, knowing that no change in relative prices had occurred. Lucas used this insight to explain why the PC in a country like Argentina with high macro volatility would be much steeper than in a country like the US with low macro volatility.

The concept of rational expectations led Lucas and his followers to make a startling prediction. He argued that anticipated monetary policy cannot change real GDP in a regular or predictable way, a result soon known as the "policy ineffectiveness proposition' (PIP). In common with Friedman and Phelps, the Lucas approach implied that movements of output away from the natural level required a price surprise, so that the central bank could alter output not by carrying out a predictable change in monetary policy but only by creating a surprise.

By the end of the 1970s the Lucas approach was widely criticized. The problem was not Lucas's introduction of rational expectations, but, rather, the twin assumptions inherited from Friedman and Phelps, namely continuous market clearing and imperfect information. Deviations of the current actual price level from the expected price were the only allowable source of business cycle movements. Thus, despite the widespread appeal of the Friedman-Phelps-Lucas approach, it ran aground on the shores of an inadequate theory of business cycles. With monthly information available on the aggregate price level, the business cycle could last no more than one month. Even Lucas later confessed that '[m]onetary shocks just aren't that important. That's the view I've been driven to. There's no question that's a retreat in my views' (Cassidy 1996, p. 53).

The demise of the information barriers model occurred in two stages. First, the theory was flawed by its inability to reconcile multi-year business cycles with one-month lags faced by agents in obtaining complete information about the aggregate price level. Second, the attempt to develop an empirical counterpart of the PIP was a research failure. It floundered on the inability to develop a symmetric explanation of output and price behavior. Barro (1977) showed that output was not related to anticipated monetary changes, an implication of the PIP, but he could not demonstrate the required corollary, which was the full and prompt responsiveness of price changes to anticipated nominal disturbances. This failure reflected the fundamental conflict between the fully flexible prices required by the information barriers model and the inflation inertia deeply embedded in the US inflation process. Soon Mishkin (1982) and Gordon (1982a) showed in historical data that anticipated monetary changes had a strong effect on output in the short run and on inflation in the long run, preserving long-run but not shortrun neutrality.

\section{THE RESURRECTION OF THE PC}

In 1974-1975 the simultaneous arrival of a sharp spike of additional inflation together with a deep recession showed that inflation and unemployment could be positively correlated, as shown for that period in the data plotted in Figure 1. Indeed we see in the graph that throughout the period 1974-1981, there was a time lead of roughly one year of inflation preceding unemployment. This further evidence against the 
negative trade-off was used by Lucas and Sargent (1978) to announce the 'wreckage' of Keynesian macroeconomics. Nevertheless, several years before their pronouncement the resurrection of the PC had begun. The first element was the new theory of policy responses to supply shocks, developed independently by Gordon (1975) and Phelps (1978) in two slightly different models that were later merged by Gordon (1984). The Gordon-Phelps model started from the proposition that the price elasticity of the demand of the commodity experiencing the adverse supply shock - for example, oil - was less than unity, so that following an increase in its relative price, the expenditure share of that commodity must increase and the expenditure share of all other components of spending must decrease. For instance, energy's share of nominal US GDP tripled between 1972 and 1981.

The required condition for continued full employment was the opening of a gap between the growth rate of nominal GDP and the growth rate of the nominal wage to make room for the increased nominal spending on oil. If nominal wages were flexible, one option would be for the growth rate of wages to become negative, allowing the growth rate of nominal GDP to remain fixed. At the alternative extreme, with rigid wages, to avoid a decline in non-energy output an accommodating monetary policy would be needed to boost nominal GDP growth by the amount needed to pay for the extra spending on oil, but this would lead to an inflationary spiral as expenditures responded to the resulting increase in the inflation rate. A third alternative, and the one that actually occurred in the 1970s, was a combination of wage rigidity with a partial upward response of nominal GDP growth, which pushed down both real non-energy spending and employment while boosting inflation. The new model helped to unify the microeconomic analysis of demand and supply with that of macroeconomic demand and supply shocks. Just as the output and price of corn or wheat could be positively or negatively correlated depending on the source of the shift in demand or supply, so the aggregate unemployment rate and the rate of inflation could be negatively or positively correlated, depending on the relative importance of aggregate demand or supply shocks.

The econometric specification of the inflation process in what I have called the "triangle model' (Gordon 1982b) contained three sets of explanatory variables representing inertia, demand, and supply. Replacing the expected inflation term was a set of long lags on past inflation, reflecting the view that the influence of past inflation on current inflation reflected generalized backward-looking inertia, not just the formation of expectations. Important sources of inertia included the set of explicit and implicit contracts that dampened short-term changes in prices and wages, and the input-output supply chain that created thousands of links of unknown magnitude and duration between changes in intermediate goods prices and the prices of final goods, as emphasized by Blanchard (1987). All of these channels interacted to create the inertia effect, the first leg of the triangle.

This approach was Keynesian because the role of inertia was to make the inflation rate slow to adjust to changes in nominal demand, and as a result real GDP emerged as a residual, not as an object of choice as in the Friedman-Phelps-Lucas model. Thus the approach was compatible with a real world in which employment adjustments were made by involuntary lay-offs rather than by withdrawal from employment as a voluntary choice. In the triangle model the speed of price adjustment and the speed of expectation formation were two different issues. Price adjustment could be delayed by wage and price contracts, and by the time needed for cost increases to percolate through the input-output table, and yet everyone could form expectations promptly and rationally based on full information about the historical response of prices to lagged values, to demand shocks, and to supply shocks. 
The demand side of the specification process for the inflation rate included the level and change of the unemployment gap, that is, the difference between the actual and natural unemployment rates. When combined with a sum of coefficients of unity on the lagged inflation terms, the specification incorporated the NRH and long-run neutrality with respect to demand shocks. The supply side of the model was represented by a set of explicit supply-shock variables, all defined so that the supply-shock term was set at zero in the absence of supply shocks. These variables included changes in the relative price of oil and of non-oil imports, and changes in the productivity growth trend, as well as dummy variables to measure the impact of the 1971-1974 Nixon-era price controls in holding down inflation and then, upon their termination in 1974, adding to the sharp 1974-1975 spike of inflation visible in Figure 1.

The first empirical challenge to the triangle model arrived almost immediately with the Volcker disinflation of 1981-1986, when, as shown in Figure 1, the inflation rate collapsed from nearly 10 percent in 1981 to around 3 percent by 1986, much faster than had been forecast by most analysts at the time. The key to the surprisingly rapid response of inflation to the high interest rates of the Volcker monetary tightening and the resulting high unemployment of the 1981-1982 recession was the role of supply shocks, and in particular the 1981-1986 decline in the relative price of energy and the 1980-1985 appreciation of the dollar that reduced the relative price of imports. ${ }^{3}$ Then the late 1980s witnessed a partial repeat of the late 1960s, with a decline in the unemployment rate during 1987-1990 accompanied by a modest acceleration of inflation. The increase of unemployment during the 1990-1991 recession brought with it a prompt decline in the inflation rate, consistent with the unemployment-gap response of the triangle model.

The behavior of inflation in the 1990s appeared to be an outlier, as the unemployment rate fell to its lowest levels since the 1960s without an acceleration of inflation. As shown in Figure 1, the inflation rate was no higher in 2000 than in 1993, despite a decline in the unemployment rate from 7 percent to slightly below 4 percent. Part of the explanation can be traced to 'beneficial' supply shocks, including lower relative prices of energy and imports and faster trend productivity growth. Another part of the explanation is that the natural rate of unemployment appears to have fallen from the 1980s to the 1990s, for reasons that were first examined by Lawrence Katz and Alan Krueger (1999). Quantitative estimates of the decline in the natural rate, which by then had become known as the NAIRU (non-accelerating inflation rate of unemployment), were provided by Douglas Staiger, James Stock, and Mark Watson (1997).

\section{CHANGING BEHAVIOR SINCE 2000}

Developments since 2000 suggest that changes have occurred in each of the three components of the triangle model. On the supply side an increase in the price of oil from about $\$ 30$ per barrel in 2004 to a brief peak of $\$ 140$ in June 2008 raised the headline inflation rate only modestly, as shown in Figure 1, and this muted response has been quantified by Blanchard and Riggi (2013). They attribute the decline in the response of overall inflation to oil-price changes to three factors: a smaller share of oil in

3. Gordon and Stephen King (1982) developed a six-equation VAR model incorporating the triangle specification with explicit links from monetary policy to unemployment, the exchange rate of the dollar, the relative price of oil, and the relative price of non-oil imports. 
production and consumption, a decline in real wage rigidity due in part to a decline in wage indexation and unionization, and more credible monetary policy.

On the demand side the slope of the PC appears to have flattened, as is evident in the modest decline of the inflation rate in response to the sharp and prolonged increase of the unemployment rate that occurred between 2008 and 2015. The contrast with the rapid decline of inflation after the 1981-1982 recession is notable, although in the earlier episode the downward path of inflation was partly propelled by lower oil prices and an appreciating dollar, whereas in 2011-2014 high oil prices dampened the downward push on aggregate inflation coming from high unemployment. Even more important in its implications for monetary policy, the feedback of past inflation to current inflation through the inertia effect appears to have lessened, so much so that Blanchard (2016) argues that inflation expectations are anchored. In his interpretation, the PC has reverted from a relationship between the change of inflation and the level of the unemployment rate, as implied by the NRH, back to its 1960s Samuelson-Solow relationship between the level of the inflation rate and the unemployment rate. This means that the monetary authority could push the unemployment rate below the natural rate at the cost of only a finite increase of inflation rather than a continuously accelerating rate of inflation. Without that acceleration, the long-run PC is no longer vertical and the Friedman-Phelps NRH is rejected 50 years after its conception.

As unemployment declined below 4 percent in 2018, it remained to be seen whether inflation would increase only modestly along a flat and anchored PC. An alternative interpretation was that the quiescence of inflation over the previous half-decade had been due to a further decline in the natural rate while the NRH remained intact. In this second interpretation there was some unemployment rate low enough to boost inflation, unleash expectations from their anchor, and generate the same type of accelerating inflation predicted by Friedman and Phelps 50 years ago.

\section{CONCLUSION}

The discovery by Phillips and his American interpreters Samuelson and Solow of an inverse relationship between inflation and unemployment briefly suggested an exploitable policy trade-off that was destroyed by the Friedman-Phelps natural rate hypothesis of the late 1960s. Exploitable trade-offs were out and long-run neutrality was in. Debates in the early 1970s centered on the models in which Friedman and Phelps had embedded the NRH, and particularly the assumption of arbitrary information barriers that prevented individual workers or firms from learning the value of macro data provided costlessly by the government. There was also controversy about the further development of the Friedman-Phelps paradigm by Lucas, who combined his assumption of rational expectations with the two FriedmanPhelps assumptions of continuous market-clearing and information barriers. The Lucas model implied the policy-ineffectiveness proposition, which held that anticipated changes in money had no effect on output and were entirely reflected in price changes. Empirical work rejected this framework, showing that monetary surprises had little effect on output, were incapable of explaining the serial correlation of output, and were inconsistent with the persistence of inflation.

This paper has reviewed one aspect of the post-1975 development of the PC literature: the triangle model that combined inflation inertia with the influence of demand and supply shocks. Demand shocks created an initial and temporary negative correlation between inflation and unemployment, and supply shocks created an initial positive 
correlation that then evolved depending on the policy response. Adverse supply shocks required policymakers to choose between higher inflation, higher unemployment, or a combination. The triangle approach emphasized that the role of past inflation was not limited to the formation of expectations, but also included pure persistence due to fixed-duration wage and price contracts as well as lags between changes in intermediate goods and final product prices. Because of this persistence built into the inflation process, changes in nominal demand growth directly translated into changes in real output growth, and changes in employment were carried out by lay-offs and other forms of rationing, not entirely by voluntary choices of workers as in the Friedman-Phelps market-clearing framework. Nevertheless, the triangle model preserved the long-run neutrality of the NRH.

The triangle model provided an explanation of the positive correlation of inflation and unemployment in the 1970s and predicted in advance the output cost of disinflation following the 1981-1982 tight money recession. Its parameters remained relatively stable in the 1980s and 1990s, and it explained the absence of accelerating inflation during the low unemployment period of the 1990s as the result of beneficial supply shocks and a decline in the natural rate of unemployment. Since 2000 its parameters appear to have shifted, with a diminished response to supply shocks, a flatter short-run PC, and a diminished response to lagged inflation that has been interpreted as the anchoring of inflationary expectations. It remains to be seen whether the economy's response to low unemployment in the next several years is a one-shot increase of inflation or a steadily accelerating inflation rate as predicted 50 years ago by Friedman and Phelps.

\section{REFERENCES}

Barro, Robert J. (1977), 'Unanticipated money growth and unemployment in the United States,' American Economic Review, 67(March), 101-115.

Blanchard, Olivier J. (1987), 'Aggregate and individual price adjustment,' Brookings Papers on Economic Activity, (1), 57-109.

Blanchard, Olivier J. (2016), 'The PC: back to the '60s?' American Economic Review Papers and Proceedings, 106(May), 31-34.

Blanchard, Olivier J. and Marianna Riggi (2013), "Why are the 2000s so different from the 1970s? A structural interpretation of the changes in the macroeconomic effects of oil prices,' Journal of the European Economic Association, 11(5), 1132-1152.

Cassidy, John (1996), 'The decline of economics,' New Yorker, 2 December, 54-57.

Fisher, Irving (1926), 'A statistical relation between unemployment and price changes,' International Labor Review, 13(June), 785-792. (Reprinted as 'I discovered the Phillips curve,' Journal of Political Economy, 81(March/April 1972), 496-502.)

Friedman, Milton (1966), 'Comment,' in George P. Shultz and Robert Z. Aliber (eds), Guidelines, Informal Controls, and the Market Place, Chicago: University of Chicago Press, pp. 55-61.

Friedman, Milton (1968), 'The role of monetary policy,' American Economic Review, 58(1), $1-17$.

Gordon, Robert J. (1975), 'Alternative responses of policy to external supply shocks,' Brookings Papers on Economic Activity, (1), 183-206.

Gordon, Robert J. (1982a), 'Price inertia and policy ineffectiveness in the United States, 1890-1980,' Journal of Political Economy, 90(December), 1087-1117.

Gordon, Robert J. (1982b), 'Inflation, flexible exchange rates, and the natural rate of unemployment,' in Martin N. Baily (ed.), Workers, Jobs, and Inflation, Washington, DC: Brookings Institution, pp. 89-158. 
436 Review of Keynesian Economics, Vol. 6 No. 4

Gordon, Robert J. (1984), 'Supply shocks and monetary policy revisited,' American Economic Review Papers and Proceedings, 74(May), 38-43.

Gordon, Robert J. and Stephen R. King (1982), 'The output cost of disinflation in traditional and vector autoregressive models,' Brookings Papers on Economic Activity, (1), 205-242.

Katz, Lawrence F. and Alan B. Krueger (1999), 'The high-pressure U.S. labor market of the 1990s,' Brookings Papers on Economic Activity, (1), 1-65.

Lucas, Robert E., Jr (1972), 'Expectations and the neutrality of money,' Journal of Economic Theory, 4(April), 103-124.

Lucas, Robert E., Jr (1973), 'Some international evidence on output-inflation tradeoffs,' American Economic Review, 63, 326-334.

Lucas, Robert E., Jr and Thomas J. Sargent (1978), 'After Keynesian macroeconomics,' in After the PC: Persistence of High Inflation and High Unemployment, Boston: Federal Reserve Bank of Boston, pp. 49-72.

Mishkin, Frederic S. (1982), 'Does anticipated monetary policy matter? An econometric investigation,' Journal of Political Economy, 90(February), 22-51.

Okun, Arthur M. (1962), 'Potential GNP: its measurement and significance,' Cowles Foundation Paper 190.

Phelps, Edmund S. (1967), 'PCs, expectations of inflation, and optimal unemployment over time,' Economica, 34(August), 254-281.

Phelps, Edmund S. (1968), 'Money-wage dynamics and labor-market equilibrium,' Journal of Political Economy, 76(July-August), 678-711.

Phelps, Edmund S. (1978), 'Commodity supply shock and full-employment monetary policy,' Journal of Money, Credit, and Banking, 10, 382-399.

Phillips, A.W. (1958), 'The relations between unemployment and the rate of change of money wage rates in the United Kingdom, 1862-1957,' Economica, 25(November), 283-299.

Samuelson, Paul A. and Robert M. Solow (1960), 'Analytical aspects of anti-inflation policy,' American Economic Review, 50(May), 177-194.

Sargent, Thomas J. (1971), 'A note on the "accelerationist" controversy,' Journal of Money, Credit, and Banking, 3(3), 721-725.

Sargent, Thomas J. and Neil Wallace (1975), 'Rational expectations, the optimal monetary instrument, and the optimal money supply rule,' Journal of Political Economy, 83(April), 241-254.

Staiger, Douglas, James H. Stock, and Mark W. Watson (1997), 'The NAIRU, unemployment, and monetary policy,' Journal of Economic Perspectives, 11, 33-49. 